\title{
ANALISIS NILAI KALOR DAN LAJU PEMBAKARAN BRIKET TONGKOL JAGUNG SEBAGAI SUMBER ENERGI ALTERNATIF
}

\author{
Dwi Pangga'), Sukainil Ahzan'1), Habibi'1), A'an Hardiyansyah Putra Wijaya'), Linda Sekar Utami'2) \\ 1)Program Studi Pendidikan Fisika, Fakultas Sains, Teknik dan Terapan, Universitas Pendidikan Mandalika, \\ Mataram, NTB, Indonesia \\ 2)Program Studi Pendidikan Fisika, FKIP, Universitas Muhammadiyah Mataram, Mataram, NTB, Indonesia
}

Corresponding author : Sukainil Ahzan

E-mail : sukainilahzan@ikipmataram.ac.id

\section{Diterima 01 November 2021, Disetujui 09 November 2021}

\begin{abstract}
ABSTRAK
Tujuan dari penelitian ini yaitu untuk menghasilkan briket tongkol jagung sebagai alternative sumber energi yang memiliki nilai kalor yang tinggi. Briket tongkol jagung dibuat dari tongkol jagung yang sudah dikeringkan dan dihaluskan sebelumnya dengan ukuran 20 mesh. Masing-masing perlakuan dicetak dengan variasi persentase perekat tepung tapioka yaitu $5 \%, 10 \%$, dan $15 \%$. Selain variasi perekat dilakukan juga variasi tekanan pembentukannya untuk melihat komposisi terbaik yang menghasilkan nilai kalor yang tinggi dan laju pembakaran yang sesuai. Briket selanjutnya diuji nilai kalor dan laju pembakarannya dengan menggunakan alat bom calorimeter. Hasil penelitian menunjukkan bahwa secara berturut-turut nilai kalor dan laju pembakaran briket dengan persentase komposisi perekat $5 \%$, $10 \%, 15 \%$ yaitu $21,00 \mathrm{~kJ}, 22,68 \mathrm{~kJ}, 31,08 \mathrm{~kJ}$, dan $12,00 \mathrm{gram} /$ menit, $13,33 \mathrm{gram} / \mathrm{menit}, 13,50$ gram/menit. Hasil terbaik dihasilkan pada komposisi persentase perekat $15 \%$ dengan nilai kalor mencapai $31,08 \mathrm{~kJ}$, dan laju pembakaran $13,50 \mathrm{gram} / \mathrm{menit}$ yang tidak terlalu jauh meningkat dibandingkan dengan komposisi persentase perekat lainnya.
\end{abstract}

Kata kunci: briket; tongkol jagung; nilai kalor; laju pembakaran

\begin{abstract}
The purpose of this research is to produce corn cobs briquettes as an alternative energy source that has a high calorific value. Corn cobs briquettes are made from corn cobs that have been dried and previously mashed with a size of 20 mesh. Each treatment was printed with variations in the percentage of tapioca starch adhesive, namely $5 \%, 10 \%$, and $15 \%$. In addition to variations of the adhesive, variations in the formation pressure were also carried out to see the best composition that produced a high heating value and an appropriate combustion rate. The briquettes were then tested for calorific value and rate of combustion using a bomb calorimeter. The results showed that the calorific value and burning rate of briquettes with the percentage of adhesive composition $5 \%, 10 \%, 15 \%$, were $21.00 \mathrm{~kJ}$, $22.68 \mathrm{~kJ}, 31.08 \mathrm{~kJ}$, and $12.00 \mathrm{gram} /$ minute, respectively. $13.33 \mathrm{grams} / \mathrm{minute}, 13.50 \mathrm{grams} /$ minute. The best results were obtained at $15 \%$ adhesive percentage composition with a calorific value of $31.08 \mathrm{~kJ}$, and a burning rate of $13.50 \mathrm{gram} /$ minute which was not significantly increased compared to other adhesive percentage compositions.
\end{abstract}

Keywords: briquettes; corn cobs; calorific value; combustion rate

\section{PENDAHULUAN}

Pengembangan energi baru dan terbarukan atau lebih dikenal dengan energi alternatif telah banyak dilakukan dengan berbagai cara antara lain energy surya melalui solar cell diubah menjadi energi listrik, energi angin melalui kincir angin diubah menjadi energi listrik, minyak nabati melalui proses esterifikasi dan transesterifikasi dengan katalis asam atau basa menghasilkan biodiesel, biomassa, yang dapat dikembangkan lebih lanjut menjadi bahan bakar padat atau briket. Biomassa adalah salah satu jenis bahan bakar padat selain batubara yang berasal dari sumber-sumber hayati seperti dari daun, rumput, limbah pertanian, limbah perkebunan dan juga limbah rumah tangga.

Potensi limbah biomassa terbesar adalah dari limbah kayu hutan, limbah padi, jagung, ubi kayu, kelapa, kelapa sawit dan tebu. Briket merupakan bahan bakar padat dapat dibuat dari biomassa yang mengandung karbon dengan nilai kalor cukup tinggi dan dapat menyala dalam waktu yang lama. Pemanfaatan briket sebagai energi alternatif merupakan pilihan yang tepat untuk menghadapi 
kelangkaan energi yang berasal dari minyak bumi.

Menurut (Nasruddin \& Affandy, 2011), penggunaan briket sebagai bahan bakar lebih murah $65 \%$ dari sumber energi pemanas dari jenis minyak tanah, gas, dan kayu. Suatu bahan bakar akan murah jika bahan baku yang digunakan banyak tersedia dan teknologi yang digunakan untuk mengolahnya sederhana. Keunggulan lain briket dari biomassa merupakan energi yang dapat diperbaharui (renewable) dan dapat diproduksi secara berkelanjutan. Pembuatan briket dari berbagai bahan seperti diuraikan di atas telah banyak dilakukan oleh para peneliti sebelumnya, seperti (Lintang Pratama, Dwi Pangga, 2020) dan (Ahzan et al., 2021) membuat briket dari eceng gondok, (Aljarwi et al., 2020) membuat briket dari sekam padi.

Demikian juga tongkol jagung merupakan salah satu bahan energi biomassa yang dapat menghasilkan energi 6,8 x 109 kkal/th (Nasruddin \& Affandy, 2011). Jika dilihat dari nilai kalor yang ada maka tongkol jagung berpotensi untuk dikembangkan lebih lanjut menjadi briket sebagai bahan bakar alternatif yang berkualitas. Selain itu ketersedian tongkol jagung dalam jumlah besar di Nusa Tenggara Barat (NTB) merupakan salah satu faktor pendukung pengembangan briket dari tongkol jagung.

Pada penelitian ini tongkol jagung dipilih sebagai bahan biomassa yang kemudian dibuat menjadi briket. $\mathrm{Hal}$ ini karena ketersediannya dalam jumlah besar baik di Pulau Lombok maupun di pulau Sumbawa. Proses perawatan yang sangat sederhana dan harga jual saat panen yang selalu tinggi menyebabkan banyak petani yang memilih untuk menanam tanaman jagung baik pada musim hujan maupun saat menjelang musim kemarau. Adanya ketersedian jagung yang sangat melimpah dan selama ini ketermanfaatan tongkol jagung yang masih minim, membuat peneliti tertarik untuk mengembangkan tongkol jagung menjadi briket.

Briket tongkol jagung yang akan dikembangkan adalah bahan bakar yang dipadatkan dan dibentuk dalam cetakan. Briket yang dibuat berbentuk kubus dan selinder/tabung dengan variasi perekat beragam. Briket memiliki berbagai jenis berdasarkan bahan dasarnya, salah satunya briket arang yang banyak digunnakan sebagai energi alternatif saat ini. Menurut (Isa, 2012) syarat briket yang baik adalah briket yang permukaannya halus dan tidak meninggalkan bekas hitam di tangan. Selain itu, sebagai bahan bakar, briket juga harus memenuhi kriteria sebagai berikut:

a. Mudah dinyalakan

b. Tidak mengeluarkan asap

c. Emisi gas hasil pembakaran tidak mengandung racun

d. Kedap air dan hasil pembakaran tidak berjamur bila disimpan pada waktu lama

e. Menunjukkan upaya laju pembakaran (waktu, laju pembakaran, dan suhu pembakaran) yang baik.

Dalam pembentukannya, berbagai variabel akan mempengaruhi kualitas dari briket yang dihasilkan. Adapun yang pertama adalah geometri pelet atau bentuk dari sebuah pelet. Menurut (Asri \& Indrawati, 2018), briket dengan bentuk silinder memiliki karakteristik lebih mudah menyala daripada briket berbentuk kotak karena jika ditata sejajar briket bentuk silinder memiliki ruang lebih banyak untuk oksigen. Sedangkan menurut (Iskandar \& Suryanti, 2016) briket bergiometri segi emapat memiliki nilai laju pembakaran lebih tinggi dari pada bentuk yang lainnya.

Varibael kedua yang mempengaruhi kualitas briket adalah tekanan. Menurut (Kathuria, 2012), peralatan yang digunakan dalam pembriketan dikategorikan ke dalam lima jenis yaitu a) densifikasi tekanan piston (Piston press densification), b) densifikasi tekanan screw (Screw press densification), c) densifikasi tekanan roll (Roll press densification), d) Pada roll press densification, e) pelet (Pelletizing).

Varibael kedua yang mempengaruhi kualitas briket adalah Bahan perekat. Selain jenis/bahan yang dijadikan perekat, komposisi/persentase bahan perekat juga sangat berpengaruh terhadap kualitas dari briket yang dihasilkan.

\section{METODE PENELITIAN}

Penelitian ini adalah penelitian eksperimental/penelitian murni di laboratorium. Dalam penelitian ini pembuatan briket menggunakan bahan dasar tongkol jagung. Tongkol jagung dihancurkan hingga ukuran menjadi halus. Variasi komposisi perekat yang digunakan yaitu $5 \%, 10 \%$, dan $15 \%$ dengan menggunakan perekat tepung tapioka. Demikian juga variasi geometri yang digunakan yaitu bentuk bentuk kotak. Hal ini mengacu dari hasil penelitian sebelumnya yaitu (Sulistyaningkarti \& Utami, 2017) yang menunjukkan bahwa perekat tepung tapioka lebih baik dari perekat tepung terigu. Penelitian serupa juga yang dilakukan oleh (Iriany et al., 2016) dan (Pangga \& Ahzan, 2019) dengan menggunakan $10 \%$ perekat diperoleh nilai 
kalor yang lebih tinggi dibandingkan dengan presentase perekat lainnya.

Tahapan pembuatan briket tongkol jagung adalah sebagai berikut:

1. Pengambilan bahan baku tongkol jagung Tongkol jagung diambil dari petani yang berada di Gunung Sari Kabupaten Lombok Barat Provinsi NTB.

2. Pembuatan serbuk tongkol jagung tongkol jagung yang sudah dikeringkan dihancurkan hingga ukurannya menjadi halus.

3. Pembuatan perekat larutan tepung kanji/tapioka

Tepung kanji dimasukkan dalam air dingin kemudian diaduk hingga rata. Setelah adukan homogen selanjutnya larutan tersebut dipanaskan hingga larutan menjadi lengket.

4. Pencampuran

Larutan perekat tepung tapioka yang sudah siap dicampurkan dengan serbuk tongkol jagung pada wadah yang sudah disiapkan dengan komposisi yang diinginkan kemudian diaduk hingga merata.

5. Pencetakan.

Adonan yang telah tercampur dengan merata, selanjutnya dicetak menjadi sampel dengan variasi tekanan dan variasi persentase bahan perekat untuk serbuk tongkol jagung yang telah ditentukan.

6. Pengeringan briket

Produk briket yang masih basah ditimbang terlebih dahulu, kemudian dikeringkan di dijemur selama 1 jam dan di oven untuk mengurangi kadar airnya.

7. Penentuan Nilai Kalor

Pengukuran nilai kalor dilakukan untuk setiap perlakuan pada setiap kali ulangan. Pada penelitian ini dalam mengukur nilai kalor akan digunakan alat uji bom kalorimeter

8. Penentuan Laju Pembakaran

Pengukuran laju pembakaran dilakukan untuk setiap perlakuan pada setiap kali ulangan.
Berikut diagram alir penelitian seperti tertera pada Gambar 1.

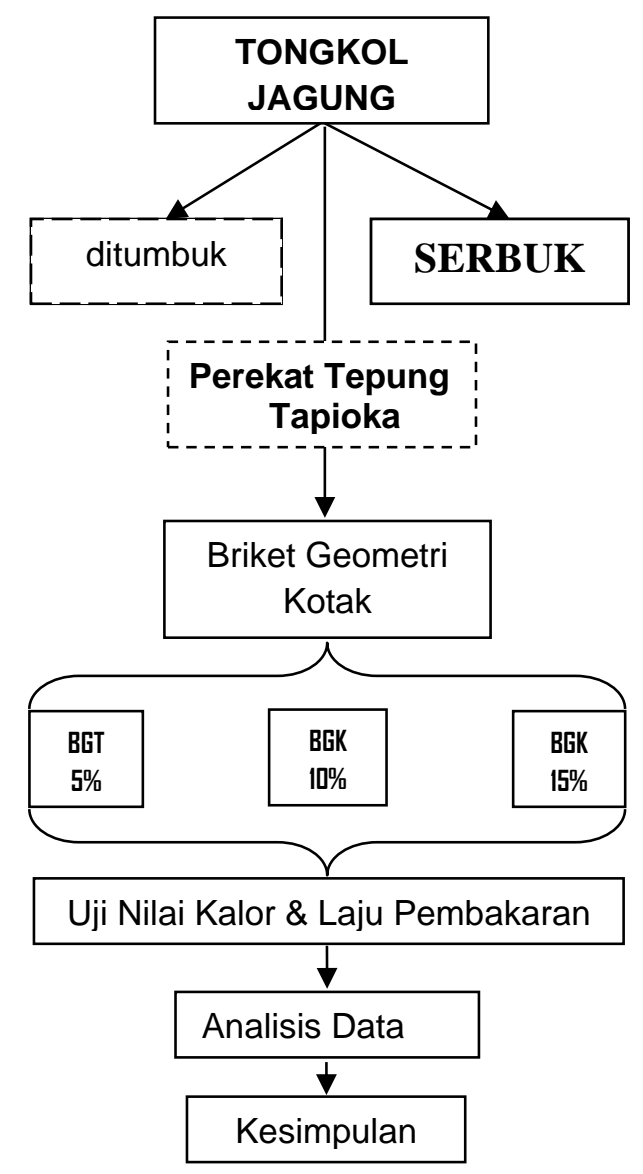

Gambar 1. Diagram Alir Penelitian

\section{HASIL DAN PEMBAHASAN}

Dalam penelitian ini pembuatan briket dilakukan dengan menggunakan tongkol jagung, pada komposisi persentase perekat tepung tapioka $5 \%, 10 \%$, dan $15 \%$. Geometri yang digunakan yaitu bentuk kotak, karena menurut (Iskandar \& Suryanti, 2016), briket geometri segi empat (kotak) memiliki nilai laju pembakaran lebih besar dari pada bentuk lain. Selain itu pembentukan briket model kotak paling cepat dan efektif digunakan pada briket tongkol jagung. Lain halnya dalam beberapa penelitian lainnya yang menggunkan arang tongkol jagung, lebih mudah merekat dan dibentuk dalam beberapa jenis geomitri baik geomitri tabung maupun kotak (Isa, 2012).

Briket tongkol jagung memiliki daya rekat lebih rendah dibandingkan briket arang tongkol jagung. Namun lebih hemat dalam penggunaan bahan/tongkol jagung dari pada briket arang tongkol jagung. Pada briket arang tongkol jagung sebagian besar bahannya habis terbakar pada saat proses sangrai/pembuatan arang. Briket tongkol jagung memiliki persentase rongga yang cukup tinggi antar 
penyusun-penyusun material briketnya (Tabel 1). Keaadaan ini memungkinkan briket ini memiliki nilai kalor dan laju pembakaran yang cukup tinggi seperti (Isa, 2012) pada Tabel 2 dan Tabel 3.

Tabel 1. Komposisi Briket Tongkol Jagung dengan beberapa variasi persentase perekat

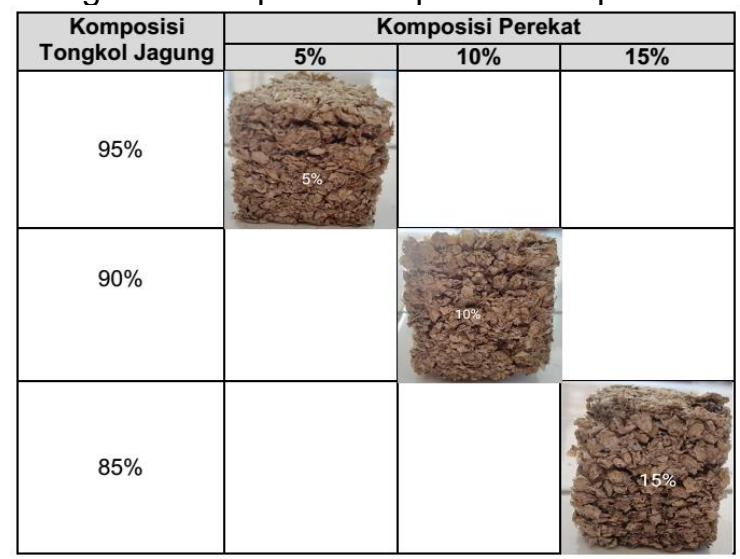

Ikatan antara material-material penyusun briket seperti terlihat pada gambar pada Tabel 1. sangat rendah, sehingga fungsi perekat (tepung tapioka) memiliki peran sangat tinggi sebagai perekat/penyambung antar serbuk-serbuk penyusun pada briket tersebut.

Tabel 2. Nilai Kalor yang dihasilkan briket tongkol Jagung dalam waktu pemanasan 6 menit

\begin{tabular}{ccccc}
\hline $\begin{array}{c}\text { Persentase } \\
\text { Perekat }\end{array}$ & $\begin{array}{c}\text { Massa } \\
\text { air } \\
(\mathrm{gr})\end{array}$ & $\begin{array}{c}\text { Perubahan } \\
\text { Suhu }\left({ }^{\circ} \mathrm{C}\right)\end{array}$ & $\mathrm{Q}(\mathrm{kJ})$ & $\mathrm{Q}$ (Kalori) \\
\hline $5 \%$ & 200 & 25 & 21.00 & 5000 \\
\hline $10 \%$ & 200 & 27 & 22.68 & 5400 \\
\hline $15 \%$ & 200 & 37 & 31.08 & 7400 \\
\hline
\end{tabular}

Pada Tabel 2. Terlihat adanya kecenderungan nilai kalor yang dihasilkan mengalami peningkatan mulai dari briket dengan komposisi persentase perekat 5\% hingga $10 \%$ pada valume briket yang sama. Nilai kalor ini menunjukkan bahwa bertambahnya persentase perekat menyebabkan semakin rapatnya jarak antar material penyusun briket, namun tidak sampai menurunkan rongga-rongga antar material secara drastis. Hal ini dapat dilihat bahwa dengan volum briket yang sama dan meningkatnya persentase perekat, massa awal briket mengalami peningkatan dari 121 gram, 131 gram, hingga 132 gram (Tabel 3).

Tabel 3. Laju Pembakaran briket tongkol

\begin{tabular}{ccccc}
\multicolumn{5}{c}{ jagung } \\
$\begin{array}{c}\text { Persentase } \\
\text { Perekat }\end{array}$ & $\begin{array}{c}\text { Massa } \\
\text { awal } \\
\text { briket } \\
\text { (gr) }\end{array}$ & $\begin{array}{c}\text { Massa } \\
\text { akhir } \\
\text { briket } \\
(\mathrm{gr})\end{array}$ & $\begin{array}{c}\text { Perubahan } \\
\text { Massa }\end{array}$ & $\begin{array}{c}\text { Laju } \\
\text { Pembakaran } \\
\text { gram/menit }\end{array}$ \\
\hline $5 \%$ & 121 & 49 & 72 & 12.00
\end{tabular}

\begin{tabular}{lllll}
$10 \%$ & 131 & 51 & 80 & 13.33 \\
\hline $15 \%$ & 132 & 51 & 81 & 13.50 \\
\hline
\end{tabular}

Terlihat juga bahwa nilai laju pembakaran pada persentase $5 \%$ perekat sebesar 12,00 gram/menit meningkat menjadi 13,33 gram/menit pada persentase perekat $10 \%$, dan meningkat lagi menjadi 13,50 gram/menit pada persentase $15 \%$ perekat. Kecenderungan meningkatnya laju pembakaran ini berkorelasi dengan terjadinya peningkatan perubahan massa dari perekat $5 \%, 10 \%$ ke $15 \%$ dengan nilai berturut-turut 72 gram, 80 gram, dan 81 gram. Laju pembakaran yang terus mengalami peningkatan juga diikuti dengan peningkatan nilai kalor yang dibuktikan dengan semakin meningkatnya temperature per 30 detik seperti terlihat pada Gambar 2. Di bawah ini.

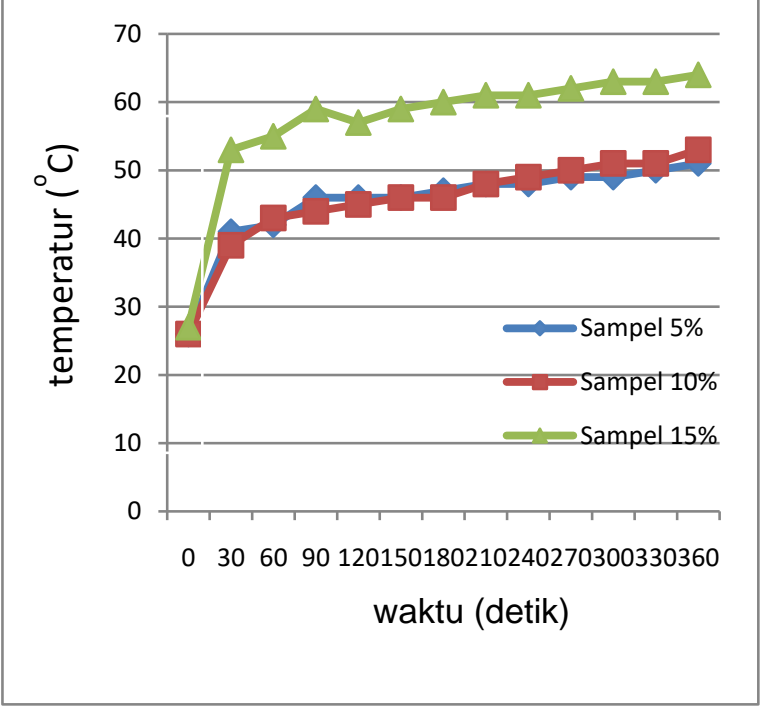

\section{Gambar 2. Grafik laju kenaikan suhu} pembakaran per 30 detik

Kenaikan temperature dari awal pembakaran hingga menit ke 6 (360 detik) terlihat grafik peningkatannya semakin melandai namun terus meningkat baik pada briket dengan persentase perekat $5 \%$ hingga $15 \%$. Briket dengan persentase perekat $15 \%$ menunjukkan peningkatan temperature lebih tinnggi dibandingkan dengan briket dengan persentase perekat $5 \%$ dan $10 \%$. Temperatur maksimum yang dicapai dalam waktu 6 menit pembakaran briket pada pemanasan $200 \mathrm{ml}$ air berturut-turut dari dari persentase perekat $5 \%$, $10 \%$, dan $15 \%$ yaitu $51^{\circ} \mathrm{C}, 53^{\circ} \mathrm{C}$, dan $64^{\circ} \mathrm{C}$.

Sedangkan hubungan antara nilai kalor dan laju pembakaran pada briket dengan persentase perekat 5\%, 10\%, dan 15\% terlihat dengan jelas pada gambar 3 berikut. 


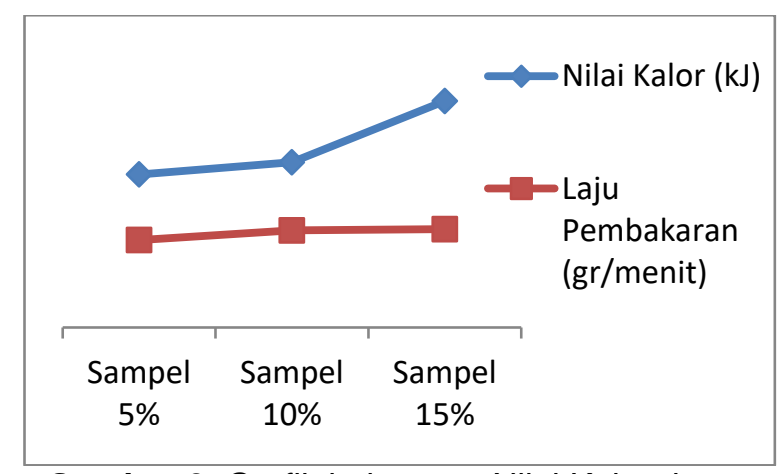

Gambar 3. Grafik hubungan Nilai Kalor dan Laju Pembakaran

Laju pembakaran mengalami peningkatan seiring meningkatnya persentase perekat, namun grafiknya masih sangat landai. Sedangkan nilai kalor mengalami peningkatan drastis dari persentase perekat $10 \%$ ke $15 \%$ yaitu dari $22,68 \mathrm{~kJ}$, menjadi $31,08 \mathrm{~kJ}$. Hasil ini menunjukkan bahwa briket dengan persentase perekat $15 \%$ memberikan hasil terbaik dengan nilai kalor 31,08 kJ, dan laju pembakaran 13,50 gram/menit.

\section{SIMPULAN DAN SARAN Simpulan}

Briket tongkol jagung dengan komposisi perekat tepung tapioka 5\%, 10\%, dan $15 \%$ menghasilkan nilai kalor dan laju pembakaran yang cukup baik. Nilai kalor dan laju pembakaran yang dihasilkan berturut-turut yaitu $21,00 \mathrm{~kJ}, 22,68 \mathrm{~kJ}, 31,08 \mathrm{~kJ}$, dan 12,00 gram/menit, 13,33 gram/menit, 13,50 gram/menit.

\section{Saran}

Untuk penelitian lebih lanjut perlu ditingkatkan dengan perlakuan variasi tekanan pembentukan briket, sehingga akan terlihat pada komposisi persentase perekat dan tekanan berapa akan dihasilkan briket terbaik dengan nilai kalor yang tinggi dan laju pembakaran yang rendah.

\section{UCAPAN TERIMAKASIH}

Ucapan terimakasih peneliti sampaikan kepada LPPM Undikma Mataram yang telah mendanai penelitian ini. Ucapan terimakasih juga kami sampaikan kepada pihak laboratorium Fisika dan Laboratorium Kimia Undikma, serta mahasiswa yang telah terlibat dan membantu dalam pengumpulan data pada penelitian ini.

\section{DAFTAR RUJUKAN}

Ahzan, S., Pangga, D., Sabda, D., \& Prasetya, B. (2021). Pengembangan Briket Berbahan Dasar Eceng Gondok dan Abu Sekam Padi sebagai Alternatif Bahan
Bakar Oven Tembakau. 7, 98-102.

Aljarwi, M. A., Pangga, D., \& Ahzan, S. (2020). Uji Laju Pembakaran dan Nilai Kalor Briket Wafer Sekam Padi dengan Variasi Tekanan. ORBITA: Jurnal Kajian, Inovasi Dan Aplikasi Pendidikan Fisika, 6(2), 200. https://doi.org/10.31764/orbita.v6i2.2645

Asri, S., \& Indrawati, R. T. (2018). Pengaruh Bentuk Briket terhadap Efektivitas Laju Pembakaran. Jurnal Penelitian Dan Pengabdian Kepada Masyarakat UNSIQ, 5(3), 338-341. https://doi.org/10.32699/ppkm.v5i3.481

Iriany, Meliza, Firman Abednego S. Sibarani, \& Irvan. (2016). Pengaruh Perbandingan Massa Eceng Gondok dan Tempurung Kelapa Serta Kadar Perekat Tapioka terhadap Karakteristik Briket. Jurnal Teknik Kimia USU, 5(1), 20-26. https://doi.org/10.32734/jtk.v5i1.1520

Isa, I. (2012). Briket Arang dan Arang Aktif dari Limbah Tongkol Jagung. Universitas Negeri Gorontalo, 1-50. http://repository.ung.ac.id/get/simlit/1/168/ 2/ Briket-Arang-Dan-Arang-Aktif-DariLimbah-Tongkol-Jagung.pdf

Iskandar, T., \& Suryanti, F. (2016). Efektivitas Bentuk Geometri dan Berat Briket Bioarang dari Bambu terhadap Kualitas Penyalaan dan Laju Pembakaran. Jurnal Teknik Kimia, 10(1), 8-12.

Kathuria, R. S. (2012). Using Agricultural Residues as a Biomass Briquetting: An Alternative Source of Energy. IOSR Journal of Electrical and Electronics Engineering, 1(5), 11-15. https://doi.org/10.9790/1676-0151115

Lintang Pratama, Dwi Pangga, D. S. B. P. (2020). Quality Analysis of Briquettes based on Waterding with Variation of Pressure and Pellet Geometry to Water Content and Value of Calories. Lensa Kependidikan Fisika, 8(2), 55-62.

Nasruddin, \& Affandy, R. (2011). Karakteristik Briket Dari Tongkol Jagung Dengan Perekat Tetes Tebu Dan Kanji. Jurnal Dinamika Penelitian Industri, 22(2), 1-10.

Pangga, D., \& Ahzan, S. (2019). Pengembangan Eceng Gondok sebagai Bahan Dasar Pembuatan Briket Sumber Energi Alternatif. 24-25.

Sulistyaningkarti, L., \& Utami, B. (2017). Making Charcoal Briquettes from Corncobs Organic Waste Using Variation of Type and Percentage of Adhesives. JKPK (Jurnal Kimia Dan Pendidikan Kimia), 2(1), 43.https://doi.org/10.20961/jkpk.v2i1.8518 